\title{
Antoni WYSOKIŃSKI
}

Ichthyology

TAXONOMIC POSITION OF HAKE, MERLUCCIUS POL YLEPIS GINSBURG, 1954, FROM THE FALKLAND ISLANDS AND TIERRA DEL FUEGO REGION

\section{POZYCJA SYSTEMATYCZNA MORSZCZUKA MERLUCCIUS POL YLEPIS GINSBURG, 1954, Z REJONU WYSP FALKLANDZKICH I ZIEMI OGNISTEJ}

\author{
Sea Fisheries Institute Branch in Świnoujście
}

\begin{abstract}
The combined biological and fisheries investigations carried out from the Polish research vessel „Profesor Siedlecki“ on the Argentine shelf resulted, among other things, in establishing the large-size hake occurrence that had not been observed before. The fish meristic characters, presented herein, correspond with those of Merluccius polylepis Ginsburg, 1954 known from the southern coast of Chile. The distribution limit for both the Argentine hakes, M.hubbsi and M.polylepis described is set in the Atlantic Ocean between 47 and $48^{\circ} \mathrm{S}$. Taxonomically, M.polylepis to the greatest extent resembles M.australis and M.paradoxus.
\end{abstract}

\section{INTRODUCTION}

In November - December 1973, the Polish research vessel „Profesor Siedlecki” carried out ichthyological investigations on the Argentine shelf between the latitudes of $39 \cdots 55^{\circ} \mathrm{S}$ within the depth range of $50-250 \mathrm{~m}$. The studies revealed the presence of two different hake species: Merluccius hubbsi Marini, 1933, and Merluccius polylepis Ginsburg, 1954, the latter not being observed in the region vbefore. (Fig. 1).

It has been accepted so far the CARPAS* Report, 1971; Angelescu et al., 1958; Svetovidov, 1948) that in the region of the Argentine shelf, from Rio de Janeiro to Cape Horn, at least to the Magellan Strait, only one hake species of a definite taxonomic

\footnotetext{
* CARPAS - Comision Asesora regional de Pesca para el Atlantico Sudoccidental.
} 


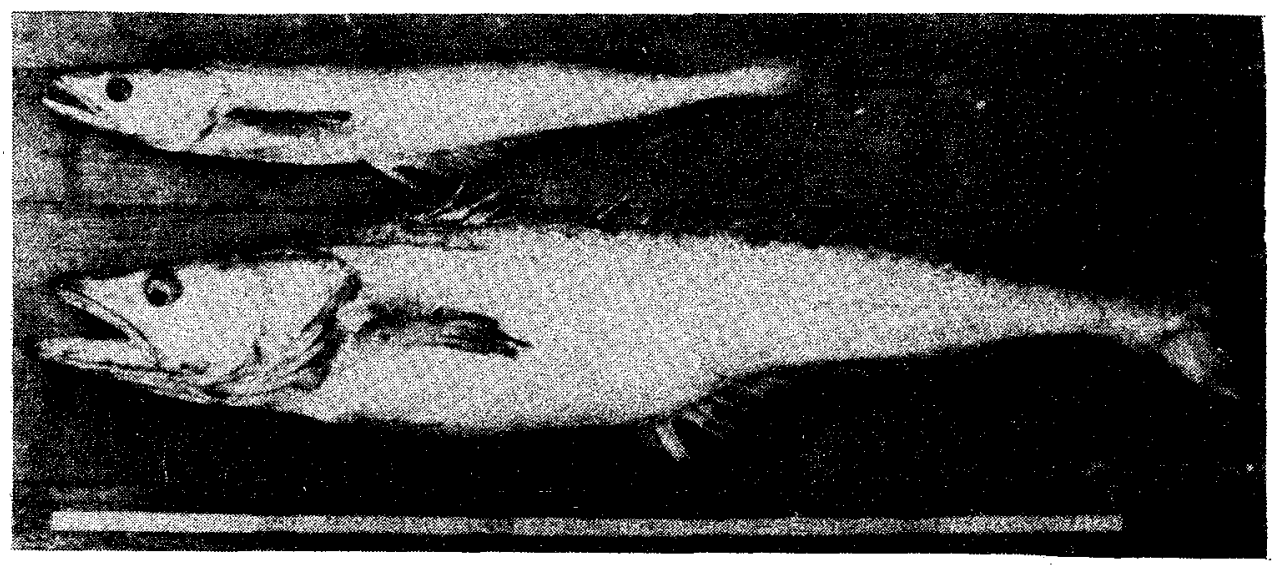

Fig. 1. Merluccius hubbsi $(1 . t .76 \mathrm{~cm})$ and $M$. polylepis $\left(1 . t .116 \mathrm{~cm}\right.$ ) caught at $48^{\circ} 45^{\circ} \mathrm{S} 60^{\circ} 58^{\circ} \mathrm{W}$ (north-eastern region of the Falkland Islands)

position occurs, namely Merluccius hubbsi Marini, 1933, or according to Angelescu (1958) M.merluccius hubbsi Marini, 1933. Only Gulland (1970) in his description of the south-western Atlantic resourçes states the presence of ,a large hake" between the Argentine coast and Falkland Islands (Malvinas), but with no comment on it whatsoever.

The present paper is aimed at determining the taxonomic position of hake from the Tierra del Fuego and Falkland Islands region and attempts to establish some relations between different hake poplations inhabiting the southern areas of the oceans.

\section{GEOGRAPHIC DISTRIBÜTION}

While M.hubbsi occurred in November-December on the Argentine shelf from the northern part of the region surveyed, i.e., from $39^{\circ} \mathrm{S}$ to $49^{\circ} \mathrm{S}$, the new species appeared from $48^{\circ} \mathrm{S}$ further to the south through the region of the Falkland Islands and Burdwood Bank to Cape Horn. Table 1 presents percentages of the two species in RV „Profesor Siedlecki" catches.

Table 1

Percentages of M.hubbsi and M.polylepis in RV „Prof. Siedlecki” catches in 1973

\begin{tabular}{|l|c|c|c|c|c|c|c|c|}
\hline \multicolumn{1}{|c|}{ Species } & \multicolumn{10}{|c|}{ Latitude, $^{\circ} \mathrm{S}$} \\
\hline & $39-$ & $41-$ & $43-$ & $45-$ & $47-$ & $49-$ & $51-$ & $53-$ \\
& -41 & -43 & -45 & -47 & -49 & -51 & -53 & -55 \\
\hline M.hubbsi & 91.4 & 81.9 & 97.2 & 66.4 & 1.6 & & & \\
M.polylepis & - & - & - & - & 0.2 & 0.3 & 3.2 & 0.8 \\
\hline
\end{tabular}


Table 2 and Fig. 2 show the locations for fishing M.polylepis in December 1973.

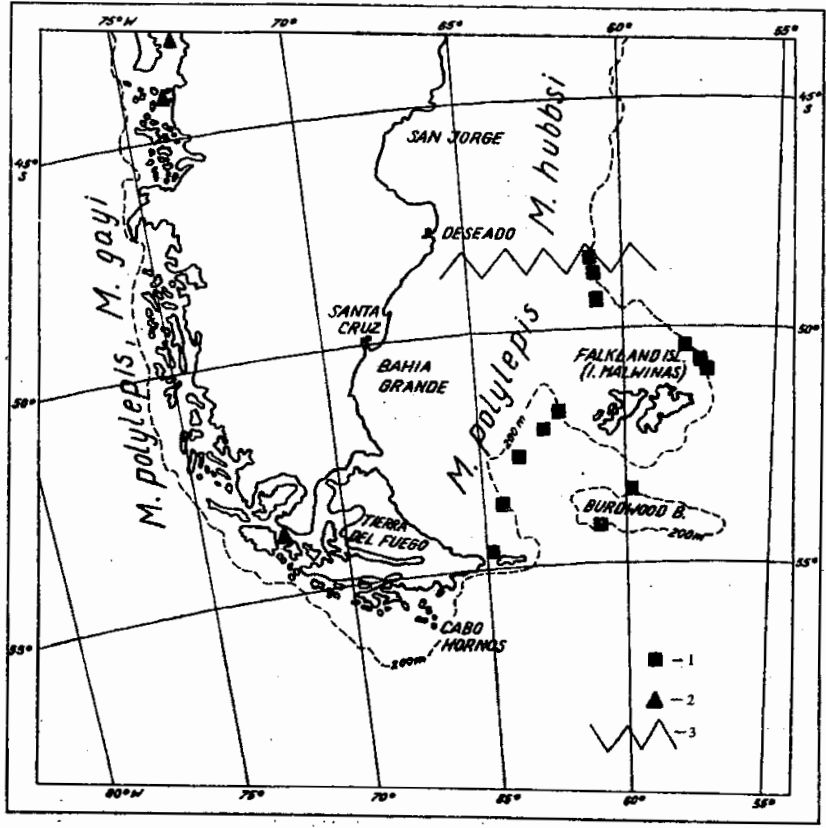

Fig. 2. Localities of catches of $M$. polylepis from the Atlantic Ocean (1, RV „Prof. Siedlecki”), the Pacific (2, after Ginsburg 1954) the southernmost occurrence limit for M. hubbsi in November-December 1973 is marked with wavy line - 3

Table 2

M.polylepis fishing locations

\begin{tabular}{|c|c|c|c|}
\hline \multirow{2}{*}{ Haul No. } & \multicolumn{2}{|c|}{ Geographic position } & \multirow{2}{*}{ No. of specimens } \\
\cline { 2 - 4 } & ${ }^{\circ} \mathrm{S}$ & ${ }^{\circ} \mathrm{W}$ & 1 \\
\hline 150 & $48^{\circ} 45^{\prime}$ & $60^{\circ} 58^{\prime}$ & 1 \\
151 & $48^{\circ} 56^{\prime}$ & $60^{\circ} 45^{\prime}$ & 2 \\
152 & $49^{\circ} 34^{\prime}$ & $60^{\circ} 53^{\prime}$ & 2 \\
153 & $50^{\circ} 42^{\prime}$ & $57^{\circ} 06^{\prime}$ & 1 \\
154 & $50^{\circ} 32^{\prime}$ & $57^{\circ} 20^{\prime}$ & 60 \\
155 & $50^{\circ} 47^{\prime}$ & $56^{\circ} 55^{\prime}$ & 3 \\
160 & $54^{\circ} 42^{\prime}$ & $60^{\circ} 35^{\prime}$ & 23 \\
161 & $53^{\circ} 47^{\prime}$ & $59^{\circ} 45^{\prime}$ & 1 \\
163 & $54^{\circ} 33^{\prime}$ & $64^{\circ} 50^{\prime}$ & 7 \\
165 & $53^{\circ} 45^{\prime}$ & $64^{\circ} 10^{\prime}$ & 58 \\
166 & $52^{\circ} 45^{\prime}$ & $63^{\circ} 45^{\prime}$ & 15 \\
167 & $51^{\circ} 50^{\prime}$ & $62^{\circ} 47^{\prime}$ & 3 \\
168 & $51^{\circ} 32^{\prime}$ & $61^{\circ} 58^{\prime}$ & \\
\hline
\end{tabular}


Meristic characters and sizes of the Atlantic M.poly?epis

Out of 177 hake specimens caught, 75 ones were subjected to taxonomic studies. The following characters were examined: vertebral count, gill-rakers count (from the first left-side gill arch), $D_{1}, D_{2}$, and $A$ fin rays counts. The measurement results are summarized in Table $3 a-e$.

Table 3

Meristic data of M-polylepis

a) Variation in vertebral counts

\begin{tabular}{|c|c|c|c|c|c|c|c|c|}
\hline $\begin{array}{c}\text { Number of } \\
\text { vertebrae }\end{array}$ & 54 & 55 & 56 & 57 & 58 & $\begin{array}{c}\text { Mean vertebral } \\
\text { count }\end{array}$ & Variance & $\begin{array}{c}\text { Number of } \\
\text { specimens } \\
\text { examined }\end{array}$ \\
\hline $\begin{array}{c}\text { percentage } \\
\text { of specimens }\end{array}$ & 3.0 & 17.9 & 53.7 & 20.9 & 4.5 & 56.6 & $0.697^{\circ}$ & 67 \\
\hline
\end{tabular}

b) Variation in $D_{1}$ fin rays count

\begin{tabular}{|c|c|c|c|c|c|c|c|c|}
\hline Number of rays & 9 & 10 & 11 & 12 & 13 & $\begin{array}{c}\text { Mean fin } \\
\text { rays count }\end{array}$ & Variance & $\begin{array}{c}\text { Number of } \\
\text { specimens } \\
\text { examined }\end{array}$ \\
\hline $\begin{array}{c}\text { percentage } \\
\text { of specimens }\end{array}$ & 1.4 & 6.8 & 63.5 & 25.6 & 2.7 & 11.2 & 0.445 & 74 \\
\hline
\end{tabular}

c) Variation in $D_{2}$ fin rays count

\begin{tabular}{|c|c|c|c|c|c|c|c|c|c|c|c|c|}
\hline $\begin{array}{c}\text { Number } \\
\text { of } \\
\text { rays }\end{array}$ & 39 & 40 & 41 & 42 & 43 & 44 & 45 & 46 & 47 & $\begin{array}{c}\text { Mean fin } \\
\text { rays } \\
\text { count }\end{array}$ & Variance & $\begin{array}{c}\text { Number } \\
\text { of speci- } \\
\text { mens exa- } \\
\text { mined }\end{array}$ \\
\hline $\begin{array}{l}\text { percen- } \\
\text { tage of } \\
\text { speci- } \\
\text { mens }\end{array}$ & 1.4 & 5.4 & 10.8 & 21.6 & 18.9 & 24.3 & 16.2 & - & 1.4 & 42.97 & 2.057 & 74 \\
\hline
\end{tabular}

d) Variation in A fin rays count

\begin{tabular}{|c|c|c|c|c|c|c|c|c|c|c|c|}
\hline $\begin{array}{c}\text { Number } \\
\text { of } \\
\text { rays }\end{array}$ & 40 & 41 & 42 & 43 & 44 & 45 & 46 & 47 & $\begin{array}{c}\text { Mean fin } \\
\text { rays } \\
\text { count }\end{array}$ & Variance & $\begin{array}{c}\text { Number } \\
\text { of speci- } \\
\text { mens exa- } \\
\text { mined }\end{array}$ \\
\hline $\begin{array}{l}\text { percenta- } \\
\text { ge of spe- } \\
\text { cimens }\end{array}$ & 1.3 & 5.4 & 14.9 & 31.1 & 21.6 & 20.3 & 2.7 & 2.7 & 43.51 & 1.952 & 74 \\
\hline
\end{tabular}


e) Variation in gill-rakers count

\begin{tabular}{|l|l|l|l|l|l|l|l|l|c|}
\hline $\begin{array}{l}\text { Number of } \\
\text { gill-reakers }\end{array}$ & 10 & 11 & 12 & 13 & 14 & 15 & $\begin{array}{c}\text { Mean gill-rakers } \\
\text { count }\end{array}$ & Variance & $\begin{array}{c}\text { Number of } \\
\text { specimens } \\
\text { examined }\end{array}$ \\
\hline $\begin{array}{l}\text { percentage of } \\
\text { specimens }\end{array}$ & 1.3 & 2.7 & 10.7 & 58.6 & 20.0 & 6.7 & 13.13 & 0.7959 & 75 \\
\hline
\end{tabular}

Average and maximum sizes of M.polylepis from the southern Argentine shelf greatly exceed those of M.polylepis off the Chilean southern coast as well as those of $M . h u b r$, M.gayi, M.capensis, M.australis, and other hake species described so far, the maxi num size of M.merluccius being the only exception (fig. 3).

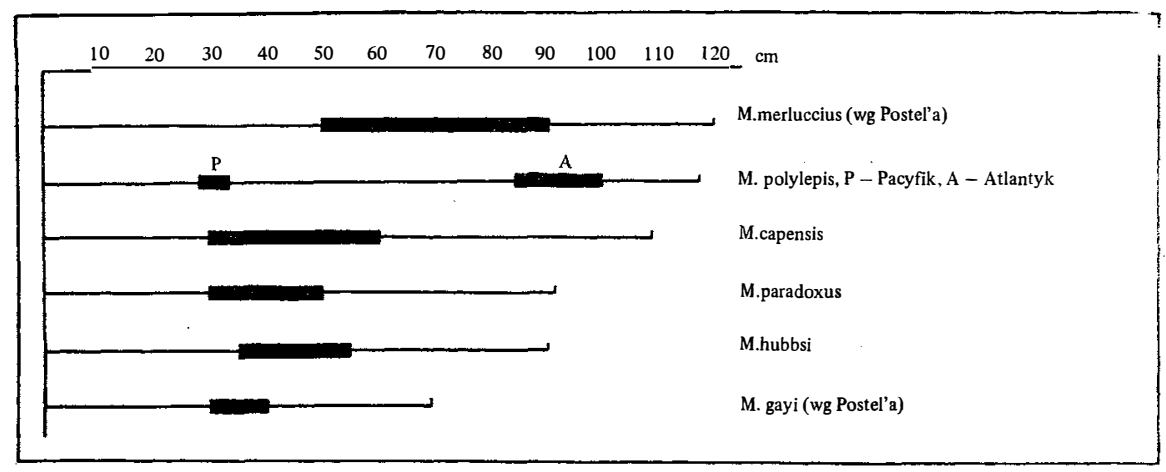

Fig. 3. Length comparison of different hake species. solid line - maximum lengths; thickened line prevailing lengths.

Results of M.polylepis length and individual weight measurements are summarized in Table 4.

Table 4

Length and weight of M.polylepis from the Argentine shelf

\begin{tabular}{|l|c|c|c|}
\hline & Males & Females & Total \\
\hline Length range, cm & $74-98$ & $68-116$ & $74-166$ \\
Mean length, cm & 86.2 & 94.1 & 94.1 \\
Modal value, cm & 86.0 & 98.0 & 86.98 \\
Length standard deviation & 6.17 & 9.88 & 9.52 \\
Individual weight, $\mathrm{g}$ & 4333 & 6176 & 5540 \\
\hline
\end{tabular}




\section{COMPARISON BETWEEN M.POL YLEPIS OF THE ARGENTINE SHELF AND THE OTHER HAKE SPECIES AND SUBSPECIES OF THE SOUTHERN HEMISPHERE}

In order to establish the taxonomic position of M.polylepis from the south-western Atlantic, the fish meristic characters were compared (Table 5) to those of the earlier described hake species inhabiting the oceanic areas. The regions and species are as follows:

south-westem Atlantic: M.hubbsi Marini, 1933;

south-eastem Atlantic: M.capensis Castelnau, 1861;

M.paradoxus Da Franca, 1954;

south-eastem Pacific: M.polylepis Ginsburg, 1954;

M.gayi (Guichenot, 1848);

south-western Pacific: M.australis (Hutton).

Apart from the species mentioned above, the other hake populations, i.e., those of M.poli Cadenat, 1952 (Guinea Bay-Angola) and M.gayi subspecies (Chile and Peru coasts) are observed to occur on the southern hemisphere. Their distribution in temperate to subtropic zones, however, as well as a rough survey of their meristic characters preclude any possibility of classifying them together with M.polylepis which is a subantaretic form.

The vertebrae, dorsal $\left(D_{1}\right.$ and $\left.D_{2}\right)$ and anal $(A)$ fin rays numbers as well as gill-rakers count have been assumed as essential criteria for distinguishing the species investigated. It turned out that the $\mathrm{D}_{1}$ fin rays count was similar in all the forms examined and could not be a distinguishing feature.

An index allowing to judge about the similarities and differences between the studied values of characters, apart from the weighed mean, was assumed as a ,z" value which was calculated as a quotient from the difference between mean for a given character in the Atlantic M.polylepis $(\overline{\mathrm{x}})$ and a corresponding character value in the species under comparison $(\mathrm{x})$, and the standard deviation $(\delta)$ :

$$
\mathbb{Z}=\frac{\bar{x}-\mathrm{x}}{\delta}
$$

The value of ,z" provides an information about the extent of similarity or difference between the characters compared. When , z" ranges from -3 to +3 , the value of character compared lies within the limits of a normal curve for the same character in the Atlantic M.polylepis, the similarity increasing when ,z" approaches 0 .

When , z" is greater or smaller than \pm 3 , the value of character compared does not lie within the normal curve for the same character in M.polylepis.

The species described exhibits appreciable differences when compared to M.hubbsi, M.gayi, and M.capensis. Its meristic characters, however, are similar to those of M.australis, M.paradoxus, and particularly to M.polylepis off the southern coast of Chile.

The significant difference between the species investigated and M.hubbsi lies in the vertebral counts amounting to 56.5 and 51.2, respectively (Fig. 4). The differences observed for the two Argentine species are almost the same in the south-African hakes, 
and according to van Eck (1971) and Soliman (1973) amount to 50 (48-51) and 55 (54-57) for M.capensis and M.paradoxus, respectively, the latter two species co-existing within one geographic region although their depth range being somewhat different. Consequently, the vertebral count is a significant difference between M.polylepis and M.capensis.

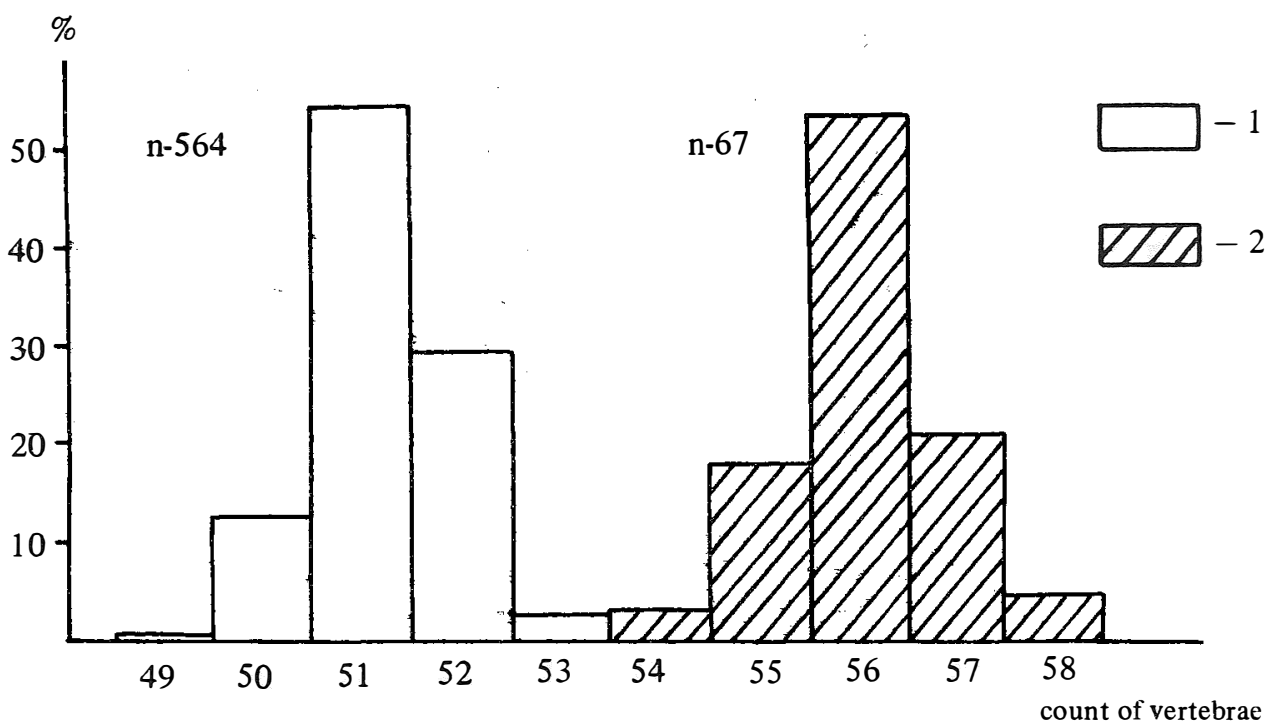

Fig. 4. Vertebral count in $M$. hubbsi (1) and $M$. polylepis (2) from the Atlantic region.

M.polylepis differs from M.gayi mainly in the gill-rakers count amounting to 7-12 and 15-18, respectively, according to Svetovidov (1948), whereas Ginsburg (1954) gives the range of 18-25 for M.gayi.

Because of a small number of individuals studied as well as the lack of osteological studies, it is very difficult to compare the meristic characters exhibiting similar values in the particular hake forms. For instance, Ginsburg (1954) established a new species of the Chilean hake, M.polylepis, basing on 5 specimens from Pacific, 2 of which had been caught off the Chiloe Islands, i.e., between $42^{\circ} 29^{\prime}$ and $43^{\circ} \mathrm{S}$, no vertebrae number being given. This species had been described earlier by Gunther, and then by Norman (1937) from 1 specimen caught off the Chile coast (Gray Harbour, Messier Channel, Magellan Strait). Norman did no find any differences between this species and M.australis while Svetovidov (1948) was of opinion that the specimen was an intermediate form between M.australis and M.gayi.

Since the literatura data are lacking as well, the vertebral count in the New Zealand M.australis was established from two radiogrammes through the courtesy of Mr Whithead of the British Museum.

The comparison reveals a greater D and A fin rays counts in the Atlantic M.polylepis than in M.australis and M.paradoxus. However, the meristic characters of M.polylepis 
Comparison of the meristic characters between the Atlantic form oi M.polylepis and the other hake species of the southern hemisphere

a) vertebral count

\begin{tabular}{|c|c|c|c|c|c|c|}
\hline \multirow{2}{*}{ Species } & \multirow{2}{*}{ Geographic region } & \multirow{2}{*}{ Author } & \multirow{2}{*}{$\begin{array}{l}\text { Number of } \\
\text { specimens } \\
\text { examined }\end{array}$} & \multicolumn{2}{|c|}{ Values of characters } & \multirow{2}{*}{$\mathrm{Z}=\frac{\overline{\mathrm{x}}-\mathrm{x}}{\delta}$} \\
\hline & & & & range & mean & \\
\hline M. polylepis & Falkland Islands & Wysokiński & 67 & $54-58$ & 56.6 & $(\delta=0.8326)$ \\
\hline M.capensis & Southern Africa & Soliman 1973 & 174 & $48-51$ & 49.9 & 8.047 outside normal curve \\
\hline M.australis & New Zealand & Radiogram British & & & & \\
\hline & & Museum & 2 & $55-57$ & 56 & $0.7206^{*}$ \\
\hline M.hubbsi & Argentina & Wysokiński & 516 & $49-53$ & 51.2 & 6.4857 outside normal curve \\
\hline M. paradoxus & Southern Africa & Soliman 1973 & 133 & $54-57$ & 55.4 & 1.4412 \\
\hline
\end{tabular}

b) $D_{1}$ fin rays count

\begin{tabular}{|c|c|c|c|c|c|c|}
\hline M.polylepis & Falkland Islands & Wysokiński & 74 & $9-13$ & 11.2 & $(\delta=0.6676)$ \\
\hline M.polylepis & Chile & Ginsburg 1954 & 4 & $11-12$ & 11.5 & 0.4493 \\
\hline M.polylepis & Magellan Strait & Norman 1937 & 1 & 10 & 10 & 1.7974 \\
\hline M.australis & & & & & & \\
\hline M.gayi & Chile & Ginsburg 1954 & 15 & $10-13$ & 11.2 & $\underline{0.0}$ \\
\hline M.hubbsi & Argentina & Wysokiński & 563 & 9.13 & 11.61 & 0.5991 \\
\hline M.capensis & Southern Africa & Soliman 1973 & 174 & $10-13$ & 10.90 & 0.4493 \\
\hline M. paradoxus & Southern Africa & Soliman 1973 & 133 & $10-12$ & 10.98 & $\underline{0.3295}$ \\
\hline
\end{tabular}

*) underlined figures indicate to a great similarity with the M.polylepis character 
c.d. table 5

c. $D_{2}$ fin rays count

\begin{tabular}{|c|c|c|c|c|c|c|}
\hline \multirow{2}{*}{ Species } & \multirow{2}{*}{ Geographic region } & \multirow{2}{*}{ Author } & \multirow{2}{*}{$\begin{array}{l}\text { Number of } \\
\text { specimens } \\
\text { examined }\end{array}$} & \multicolumn{2}{|c|}{ Values of characters } & \multirow{2}{*}{$\mathrm{z}=\frac{\overline{\mathrm{x}}-\mathrm{x}}{\delta}$} \\
\hline & & & & range & mean & \\
\hline M. polylepis & Falkland Islands & Wysokiński & 74 & $39-47$ & 42.97 & $(\delta=1.5787)$ \\
\hline M. polylepis & Chile & Ginsburg 1954 & 4 & $43-45$ & 43.75 & 0.6334 \\
\hline M.polylepis & Magellan Strait & Norman 1937 & 1 & 42 & 42 & 0,6144 \\
\hline M.gayi & Chile & Ginsburg 1954 & 14 & $36-42$ & 39.5 & 2.198 \\
\hline M.hubbsi & Argentina & Wysokiński & 564 & $33-40$ & 37.22 & $\begin{array}{l}3.6422 \text { outside nor- } \\
\text { mal curve }\end{array}$ \\
\hline M.australis & New Zealand & Svetovidov 1948 & $?$ & $36-43$ & ca 39.5 & 2.198 \\
\hline M. capensis & Southern Africa & Soliman 1973 & 174 & $37-42$ & 39.74 & 2.0459 \\
\hline M. paradoxus & Southern Africa & Soliman 1973 & 133 & $38-42$ & 40.6 & 1.5012 \\
\hline
\end{tabular}

d. A fin rays count

\begin{tabular}{|c|c|c|c|c|c|c|}
\hline M.polylepis & Falkland Islands & Wysokiński & 74 & $40-47$ & 43.51 & $(\delta=1.397)$ \\
\hline M.polylepis & Chile & Ginsburg 1954 & 4 & $42-45$ & 43.25 & $\underline{0.1861}$ \\
\hline M.polylepis & Magellan Strait & Norman 1937 & 1 & 42 & 42 & 1.0808. \\
\hline M.gayi & Chile & Ginsburg 1954 & 15 & $39-42$ & 39.8 & 1.6556 \\
\hline M.hubbsi & Argentina & Wysokiński & 564 & $34-41$ & 37.83 & $\begin{array}{l}4.0229 \text { outside normal } \\
\text { curve }\end{array}$ \\
\hline M.australis & New Zealand & Svetovidow 1948 & & $36-42$ & 39.0 & $\begin{array}{l}3.2283 \text { outside normal } \\
\text { curve }\end{array}$ \\
\hline M.capensis & Sothern Africa & Soliman 1973 & 174 & $37-42$ & 39.89 & 2.5912 \\
\hline M. paradoxus & Southern Africa & Soliman 1973 & 133 & $38-42$ & 40.66 & 2.0400 \\
\hline
\end{tabular}


c.d. table 5

e. Gill-rakers count (on upper and lower arches)

\begin{tabular}{|c|c|c|c|c|c|c|c|}
\hline \multirow{2}{*}{ Species } & \multirow{2}{*}{ Geographic region } & \multirow{2}{*}{ Author } & \multirow{2}{*}{$\begin{array}{l}\text { Number of } \\
\text { specimens } \\
\text { examined }\end{array}$} & \multicolumn{2}{|c|}{ Values of characters } & \multirow{2}{*}{\multicolumn{2}{|c|}{$z=\frac{\bar{x}-x}{\delta}$}} \\
\hline & & & & range & mean & & \\
\hline M.polylepis & Falkland Islands & Wysokiński & 75 & $10-15$ & 13.13 & $(\delta=0, \delta$ & 03) \\
\hline M. polylepis & Chile & Ginsburg 1954 & 8 & $13-15$ & 14.125 & 1.1176 & \\
\hline M. polylepis & Magellan Straits & Norman 1937 & 1 & 12 & 12 & 1.2692 & \\
\hline M.gayi & Chile & Ginsburg 1954 & 30 & $18-25$ & 21.0 & 8.8397 & $\begin{array}{l}\text { outside nor- } \\
\text { mal curve }\end{array}$ \\
\hline M.hubbsi & Argentina & Wysokiński & 564 & $12-17$ & 14.22 & 1.2243 & \\
\hline M.australis & New Zealand & Svetovidow 1948 & & $10(\mathrm{c}$ & r arch) & & \\
\hline M.capensis & Southern Africa & Soliman 1973 & 174 & $16-21$ & 18.64 & $\underline{6.1889}$ & $\begin{array}{l}\text { outside nor- } \\
\text { mal curve }\end{array}$ \\
\hline M. paradoxus & Southern Africa & Soliman 1973 & 133 & $17-23$ & 20.17 & 7.9074 & \\
\hline
\end{tabular}


from the Atlantic and Pacific Oceans are very similar and overlapping, the „,z" values for all the characters compared being the smallest and nearest to 0 .

Thus, there is no reason to distinguish at present state of knowledge, within the species of M.polylepis, between the „Atlantic population” and the „Pacific one”, especially in view of the fact that the individuals belonging to the same population can penetrate from the Atlantic Ocean into the Pacific and vice versa through the Magellan Strait and around Cape Horn. Presumably the constant migration routes and periods of each year-class or its groups could be detected. For instance, M.polylepis of length over $36 \mathrm{~cm}$ has not been observed off the coast of Chile, while in the Atlantic waters only large individuals $(76-117 \mathrm{~cm})$ occur.

\section{DISCUSSION}

The comparison between the meristic charaters comprised in Table 5 indicates that various subantarctic o, deep-water hake forms (M.polylepis, M.australis, M.paradoxus) show only minor differences. All the forms have their vertebral counts ranging within 54-58 (no data available for M.polylepis off Chile), gill-rakers counts from 7 do $12, \mathrm{D}_{2}$ and A fin rays numbers from 36 to 47 .

In opposition to this group another one containing the remaining hake forms distributed within temperate zones of both hemispheres and having their vertebral counts not exceeding 53 can be placed. The latter group comprises M.merluccius (50.48-51.15), M.mediterraneus (52), M.poli (53), M.capensis (50), M.hubbsi (51.2).

The different geographic as well as vertical distribution on the one side and temperature (thermal?) regime on the another separating the hake population contribut to significant differences between hake forms and their meristic characters in both groups.

According to studies carried out by Fage (1958), increased numbers of vertebrae as well as dorsal and anal fin rays result among other things From lower temperature influencing the embryonic stages. At the same time,the different preferences to the spawning thermal conditions exist in each hake population and they become philogenetically fixed. For instance, M.hubbsi lives in $6-8^{\circ} \mathrm{C}$ and spawns in about $12^{\circ} \mathrm{C}$, whereas M.polylepis has been caught from the water layers of $4.5-7^{\circ} \mathrm{C}$. M.capensis stays in $7^{\circ}-9,5^{\circ} \mathrm{C}$, average $8,2^{\circ} \mathrm{C}$ and M.paradoxus in the same region between $5,1^{\circ}-8,4^{\circ} \mathrm{C}$, average $6,7^{\circ} \mathrm{C}$ (Kuderskij 1973). The fixed thermal preferences of the species, influencing the vertebral and fin rays counts appear to be a distinctive feature for each population.

Thus, we can assume an hypothesis that the hakes with similar meristic characters and thermal requirements forms some groups of species. Among them M.polylepis, M.australis, M.paradoxus forms the subantarctic cold-water group and derives probably from common ,praspecies”. Another group like M.merluccius, M.capensis, M.hubbsi could be connected with ,praspecies” from temperate zone. They could explain the similarities in meristic characters in the different hake populations in spite of land and distance barriers separating them. 
A peculiar nature of hake occurrence in the world ocean becomes also understandable. In many geographic regions 2 hake species of definite differences in their vertebral counts either co-exist or occur in close neighbourhood. The „pairs” are as follows: Merluccius merluccius (51) and M.senegalensis (54.5) off the north-western Africa, M.capensis (50) and deep-sea M.paradoxus (55) off the southern Africa, the temperate zone M.hubbsi (51.2) and the subantarctic M.polylepis (56) off the Argentine coast.

M.polylepis mentioned above and M.gayi also form a ,pair” as evidenced by the differences in their paired fin rays counts (Ginsburg, 1954).

The nature of geographic distribution of M.polylepis presented herein against the general pattern of distribution of hake populations and their meristic characters indicate to affinities of the species discussed to the non-thermofilic hake group with the species such as M.australis, deep-sea M.paradoxus, and M.senegalensis, due to the common characters with these species.

\section{REFERENCES}

Angelescu V., Gneri F., Nani A., 1958: La merluza del Mar Argentino (Biologia y Taxonomia). Secretaria de Marina. Buenos Aires: 1-224.

Eck T.H. van, 1971: The South African Hake: Merluccius capensis - or Merluccius paradoxus. The South Africain Shipping News and Fishing Industry Rewiew, December:

Fage L., 1958: Croissance - Races - Migrations. In P.P. Grassé: Traité de Zoologie, Agnathes et Poissons. Paris. XIII, III: 1835-1884.

FAO Conference on Fishery Management and Development, 1973: Fishing News Intern. 12, 5.

Gulland J.A., 1970: The Fish Resources of the Ocean. FAO, Rome.

Kuderskij C.K., 1973: Nekotoryje osobennosti raspredelenija merluz Juznoj Afriki $\left(25-35^{\circ} \mathrm{S}\right) \mathrm{v}$ zavisimosti ot gidrologiceskih uslovii. Trudy Atlant-NIRO. Kaliningrad. LIII.

Postel E., 1966: Le merlu et sa pêche. La Pêche Maritime, No 1064, Janv.

„Report", 1973: Informe del Grupo de Trabaho Conjunto CAIRM) CARPAS, Primera Reunion, Montevideo, Uruguay, 14 al 17 de Diecembre de 1971. FAO, Rome, Julio 1973. (typescript).

Soliman I.A., 1973: Variations of fishes of genus Merluccius in Atlantic Ocean and Mediterranean Sea. Acta Ichthyologica et Piscatoria. Szczecin. III, 2.

Svetovidov A.N., 1948: Fauna SSSR, Ryby, Treskoobraznyje. Akad. Nauk. SSSR. Moskva-Leningrad.: $1-221$.

Translated: mgr Teresa Radziejewska

\section{POZYCJA SYSTEMATYCZNA MORSZCZUKA MERLUCCIUS POL YLEPIS GINSBURG, 1954 Z REJONU WYSP FALKLANDZKICH I ZIEMI OGNISTEJ}

\section{Streszczenie}

W trakcie badań nad populacją morszczuka szelfu argentyńskiego przeprowadzonych $w$ listopadzie - grudniu 1973 na badawczym statku „Profesor Siedlecki” stwierdzono występowanie dwu gatunków rodzaju Merluccius: M. hubbssi, Marini i M.polylepis, Ginsburg. Gatunki te posiadają wyraźnie różną charakterystykę cech merystycznych (Fig. 4) jak i długości osobniczej (Fig. 3). Granica dzieląca występowanie geograficzne obydwa gatunki przebiega pomiędzy $47^{\circ}$ i $48^{\circ} \mathrm{S}$ (Fig. 2).

Analiza porównawcza cech merystycznych M.polylepis i pozostałych gatunków morszczuków półkuli południowej (Tab. 5) przy uwzględnieniu ich termicznych wymagań oraz ich szczególnego 
rozmieszczenia geograficznego pozwoliły na wysunięcie hipotezy o istnieniu co najmniej dwu grup gatunków powiązanych wspólnym pochodzeniem. Jedna $\mathrm{z}$ nich to grupa gatunków subantarktycznych złożona z M.australis, M.polylepis oraz M.paradoxus, wykazująca bardzo zbliżone cechy merystyczne jak i wymagania termiczne. Druga grupa to gatunki wywodzące się ze strefy umiarkowanej do której zaliczyć można m.innymi M.merluccius, M.capensis i M.hubbsi.

ПОЛОЖЕНИЕ МЕРЛУЗЫ (Merlucius polylepis Ginsburg, I954) ИЗ РАЙОНА ФОЛКЛЕНДСКИХ ОСТРОВОВ И ОГНЕННОЙ ЗЕМЛИ

В СИСТЕМАТИКЕ РЫБ

$$
P \text { e } 5 \text {. }
$$

В ходе исследований над популяцией мерлузы аргентинского шельфа, проводимых в ноябре - декабре I973 г. с исследовательского судна " Профессор Сёдлецки", обнаружены два вида из рода Merluccius : M.hubbsi Marini и М. polylepis Ginsburg. Эти виды заметно отличаются друг от друга как своими меристическими признаками, (Рис. 4), так и индивидуальной длиной (Рис. 3). Граница, разделяющая географическое размещение обоих видов, проходит между $47^{\circ}$ и $48^{\circ}$ ю.ш. (Рис. 2).

Сравнительный анализ меристических признаков м.polylepis и остальных видов мерлузы южного полушария (Табл. 5) при учёте их термических потребностей и особенностей их географического размещения позволил выдвинуть гипотезу о существовании по крайней мере двух видовых групп, обьединённых общим происхождением. Одна из них - это группа субантарктических видов, состоящая из м.australis, весьма сходные меристические признаки и термические потребности. Вторая группа - это виды, происходящие из умеренной зоны, к которой можно отнести также и M.merluccius, j.capensis i M.hubbsi.

Address:

Received: 14 IX 1974 r.

Mgr Antoni Wysokiński

Morski Insty tut Rybacki

Oddział w Świnoujściu

Polska - Poland 